\title{
$\mathrm{Cu}$ foam / $\mathrm{Cu}$ plate 간 고상확산접합부의 인장성질에 미치는 접합압력과 유지시간의 영향
}

\author{
김상호 ${ }^{1} \cdot$ 허회준 $^{1} \cdot$ 윤태진 $^{2} \cdot$ 강정윤 $^{1, *}$ \\ ${ }^{1}{ }^{1}{ }$ 산대학교 재료공학과 \\ ${ }^{2}$ 부산대학교 하이브리드소재솔루션 핵심연구센터
}

\section{Effect of Bonding Pressure and Bonding Time on the Tensile Properties of Cu-Foam / Cu-Plate Diffusion Bonded Joint}

\author{
Sang-Ho Kim ${ }^{1}$, Hoe-Jun Heo" ${ }^{1}$, Tae-Jin Yoon ${ }^{2}$, and Chung-Yun Kang ${ }^{1, *}$ \\ ${ }^{l}$ Depart. of Material Science and Engineering, Pusan National University, Busan 46241, Republic of Korea \\ ${ }^{2}$ National Core Research Center, Pusan National University, Busan 46241, Republic of Korea
}

\begin{abstract}
Open cell $\mathrm{Cu}$ foam, which has been widely utilized in various industries because of its high thermal conductivity, lightweight and large surface area, was successfully joined with $\mathrm{Cu}$ plate by diffusion bonding. To prevent excessive deformation of the $\mathrm{Cu}$ foam during bonding process, the bonding pressure should be lower than $500 \mathrm{kPa}$ at $800{ }^{\circ} \mathrm{C}$ for 60 min and bonding pressure should be lowered with increasing holding time. The bonding strength was evaluated by tensile tests. The tensile load of joints increased with the bonding pressure and holding time. In the case of higher bonding pressure or time, the bonded length at the interface was usually longer than the cross-sectional length of the foam, so fracture occurred at the foam. For the same reason, base metal (foam) fracture mainly occurred at the node-plate junction rather than in the strut-plate junction because the bonded surface area of the node was relatively larger than that of the strut.
\end{abstract}

(Received May 4, 2016; Accepted June 2, 2016)

Keywords: foams, diffusion bonding, mechanical properties, tensile test, fractograph

\section{1. 서 론}

금속폼(metal foam)은 내부에 기공이 존재하는 금속소재 이다. 금속폼은 기존의 금속소재에 비하여 비중이 매우 낮으 며 비강도와 충격 흡수능이 높기 때문에 경량성, 내충격성이 우수한 특성을 지닌다 [1,2]. 특히 개포형 금속폼(open cell metal foam)은 금속 내 기공이 서로 이어진 형상을 가져 유체 가 기공을 통해 이동할 수 있으며, 가스 투과율이 높고, 단위 부피당 면적비가 크기 때문에 열, 전기 전도도가 상대적으로 높은 장점을 가진다. 또한 고체 매질 사이의 복잡한 유로에 의하여 발생하는 유체의 교란 및 혼합효과가 크기 때문에 전 열촉진에 유용한 특성 [3-10]을 가져 금속폼은 열교환기용 소재로 각광받고 있다 [11,12].

* Corresponding Author: Chung-Yun Kang [Tel: +82-51-510-2428, E-mail: kangcy@pusan.ac.kr] Copyright (c) The Korean Institute of Metals and Materials
한편, 금속폼을 이용한 열교환기의 형상은 주로 판재, 폼 재, 판재를 적층한 샌드위치(sandwich) 형상과 튜브 내부에 폼재를 삽입하거나, 외부에 폼재를 둘러 싼 후 판재로 케이싱 (casing) 하는 쉘앤튜브(shell and tube) 방식이 대표적이다. 이와 같은 금속폼 열교환기의 제작을 위하여 금속폼과 판재 의 체결 및 접합 공정 개발이 필수적이다.

현재 금속폼과 판재 혹은 튜브 등의 소재를 연결하기 위하 여 주로 기계적 체결방식을 사용하고 있으나, 기계적 체결부 의 강도가 낮을 뿐만 아니라 접촉 열저항이 높아 열전도가 감 소하는 문제점이 보고되고 있다 [13]. 따라서 금속폼 열교환 기를 제작하기 위해서는 직접적으로 열 교환이 발생하는 영 역에 대한 용접, 접합 공정 연구가 중요하다.

현재 보고된 금속폼의 접합방법은 접착제 접합(adhesive bonding), 솔더링(soldering), 브레이징(brazing), 레이저 용접 (laser welding) 등이 있다 [14-17]. 접착제 접합과 솔더링은 접착제와 솔더의 낮은 융점으로 인하여 고온 환경에서 사용 


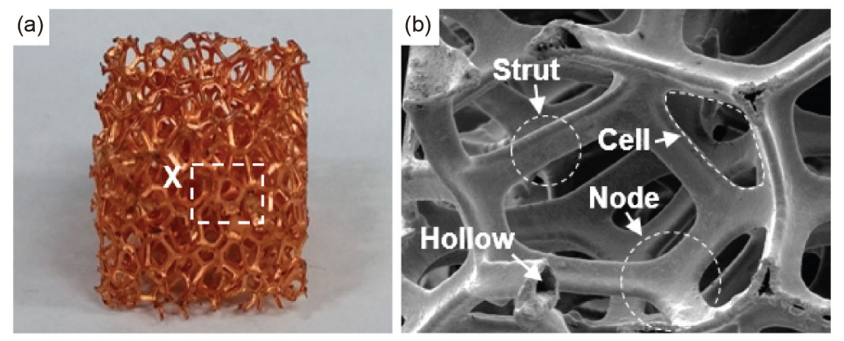

Fig. 1. (a) Shape of 30 PPI open cell $\mathrm{Cu}$ foam and (b) SEM micrograph of $\mathrm{X}$ in (a).

이 제한된다. 브레이징은 판재와 금속폼 사이의 삽입금속을 접합온도에서 용융시킨 후, 용융된 삽입금속이 모세관 현상 에 의하여 판재와 금속폼 사이를 채우게 되어 접합이 되는 방 법이다. 이 때 금속폼의 피접합면적이 판재보다 상대적으로 좁기 때문에 용융 삽입금속이 남게되고, 이것이 금속폼 내부 로 침투하여 유로를 막는 문제점이 발생한다 [16]. Mrityunjay Singh 등은 삽입금속 또는 접착제를 사용하지 않 고 에너지 투입을 국소적으로 제한하여 좁은 영역의 용접이 가능한 레이저 용접을 적용하였다. 그러나 레이저 용접 적용 시, 모재 용융부에서 수축 변형이 발생하고, 용융된 모재가 기공내부로 침투하여 유로가 막히거나, 용융부 주위의 금속 폼이 열화되어 강도가 저하하는 문제점을 보고하였다 [17]. 따라서 금속폼의 접합, 용접 시 발생하는 문제는 대부분 액상 의 유/무와 관계된 것을 알 수 있다.

한편, 고상확산접합은 접합계면의 항복 및 크립(creep) 변 형에 의하여 접합부의 밀착면적이 증가하면서 입계의 이동 에 의하여 접합이 되는 원리이며, 접합계면에서 삽입금속 및 모재를 용융시키지 않고 고상상태로 접합이 되기 때문에 모 재와 거의 같은 강도를 기대할 수 있다. A. A. Shirzadi 등은 일반적으로 금속폼의 고상확산접합부에서 충분한 강도를 얻 기 위하여, 접합압력이 금속폼의 고온항복강도를 초과해야 한다고 보고하였으나 [18], 최근 Brittany Hamilton 등은 orthopedic implant용 Ti-6Al-4V(노출 기공률 45\%) 소재의 금속폼과 판재에 고상확산접합을 실시하여, 금속폼보다 높 은 강도를 갖고 접합부에 결함이 없는 금속폼과 판재 간 고상 확산접합이 가능하다고 보고하였다 [19].

따라서 본 연구에서는 마이크로(micro) 열교환기의 조립 공정 개발을 목적으로, 열전도율이 우수한 구리 소재의 금속 폼과 판재 간 고상확산접합을 실시하고, 접합압력과 유지시 간에 따른 금속폼의 변형과 고상확산접합부의 인장성질 변 화를 검토하였다.

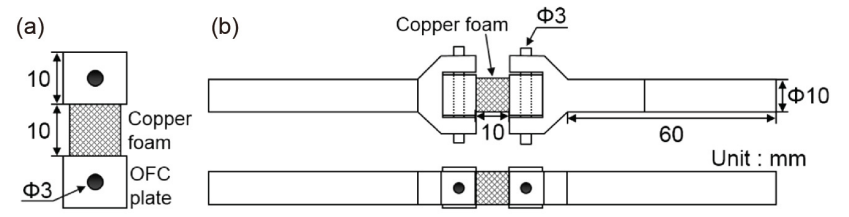

Fig. 2. (a) Specimen for tensile test and (b) setup used for tensile testing of foam/plate diffusion bonded joints.

\section{2. 사용재료 및 실험방법}

본 연구에서는 전기 도금법(electro-deposition)으로 제작 된 기공률 $96 \%$, 평균 기공 크기 $~ 600 \mu \mathrm{m}$ 의 $30 \mathrm{PPI}$ (pore per inch), 개포형 구리폼(구리폼, $\mathrm{t}=10.0 \mathrm{~mm}$ )과 무상소동 판재 (구리판, $\mathrm{t}=10.0 \mathrm{~mm}$ )를 사용하였다. 구리폼은 속이 비어있 는 가지 형상의 strut가 node를 통해 서로 이어져 셀(cell) 형 상으로 구성되어 있으며, 그 사진을 그림 1에 나타내었다. 접 합형태는 그림 2 (a)와 같이 구리판과 구리폼을 샌드위치 구 조로 배치하였으며, 폼과 판재간 피접합면의 면적을 높이기 위하여 피접합면을 경면 연마 후 접합을 실시하였다.

고상확산접합에 의한 구리폼의 변형을 최소화하기 위하 여, 접합온도는 자중만으로 순동 간 고상확산접합이 가능한 온도인 $800{ }^{\circ} \mathrm{C}$ 로 선정하였으며 [20], 고상확산접합은 $1.5 \times 10^{-5}$ torr의 고진공 분위기의 진공로에서 $13.3{ }^{\circ} \mathrm{C} / \mathrm{min}$ 의 승온 속도로 접합온도까지 가열, 유지한 후 로냉하였다. 유지 시간은 $30 ~ 150$ 분의 범위에서 30 분 간격으로 변화시켰고, 접 합압력은 시편 위에 무게추를 얹어 가해주었으며, 구리폼의 피접합 면적을 기준으로 $20 \sim 500 \mathrm{kPa}$ 의 범위에서 $80 \mathrm{kPa}$ 간 격으로 변화시켰다.

접합 후 접합부의 미세조직은 연마 후 Distilled water 50 $\mathrm{mL}+\mathrm{H}_{2} \mathrm{SO}_{4} 4 \mathrm{~mL}+\mathrm{K}_{2} \mathrm{Cr}_{2} \mathrm{O}_{7} 1 \mathrm{~g}+2$ drop of $\mathrm{HCl}$ 혼합용액 으로 부식시킨 후 광학현미경 및 주사전자현미경(Scanning electron microscope, SEM)으로 관찰하였다. 인장 시험 시험 편은 그림 2에 나타낸 바와 같이, 구리판에 직경 $3 \mathrm{~mm}$ 의 홀 (hole)을 가공하여 접합된 시험편과 인장시험용 지그(jig)를 환봉으로 체결한 후, 크로스헤드 속도(cross-head speed) 1 $\mathrm{mm} / \mathrm{min}$ 의 조건으로 인장시험을 실시하였다.

\section{3. 결과 및 고찰}

\section{1 폼의 형상 변화에 미치는 접합조건의 영향}

그림 3 은 구리폼과 구리판을 $800{ }^{\circ} \mathrm{C}$ 에서 각각 (a) 100 , (b) 


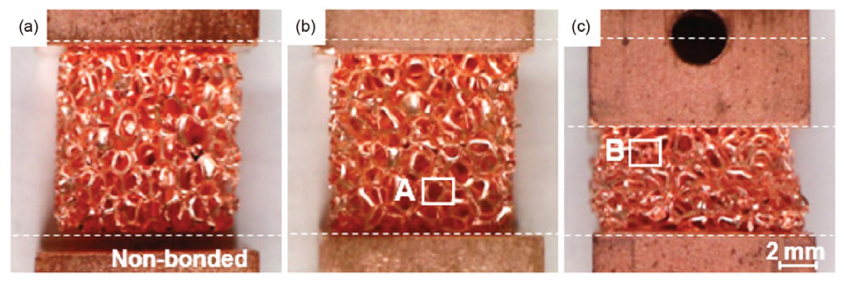

Fig. 3. Close-up image of typical diffusion bonded $\mathrm{Cu}$ foam $/ \mathrm{Cu}$ plate; (a) non bonded, (b) bonded, and (c) deformed specimen, respectively [bonding conditions: $800{ }^{\circ} \mathrm{C}, 60 \mathrm{~min}$, and (a) 100 $\mathrm{kPa}$, (b) 420, (c) $500 \mathrm{kPa}$.

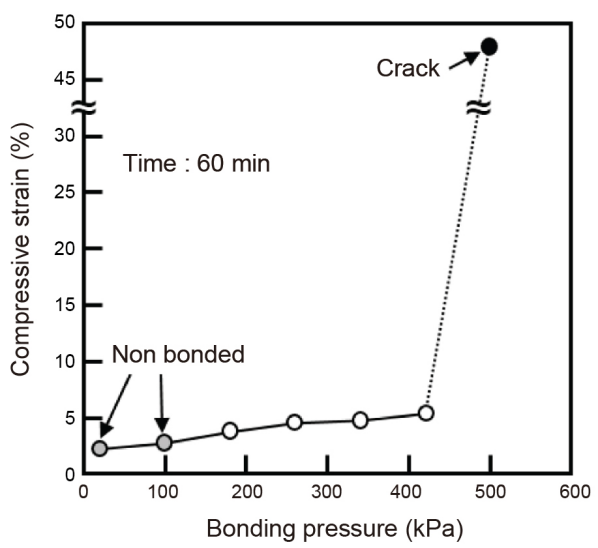

Fig. 4. Compressive strain of $\mathrm{Cu}$ foam with bonding pressure at $800{ }^{\circ} \mathrm{C}$ for $60 \mathrm{~min}$.

420 , (c) $500 \mathrm{kPa}$ 의 압력으로 60 분 동안 유지하여 확산접합 한 접합시편의 대표적인 형상을 나타낸 것이고, 그림의 점선 은 접합 전 폼과 판재의 최초 경계면을 나타낸 것이다. 그리 고 그림 4 는 $800{ }^{\circ} \mathrm{C}$ 에서 60 분 동안 유지하여 접합한 경우, 접 합압력에 따른 폼의 압축변형률 변화를 나타낸 것이다. 여기 서, 압축변형률은 구리폼의 최초 높이 대비 접합 후 감소된 높이로 하였다. $100 \mathrm{kPa}$ 이하의 압력에서는 그림 3(a)의 아랫 부분과 같이 접합이 되지 않았고, $500 \mathrm{kPa}$ 압력에서는 그림 3 의 (c)와 같이 심하게(40.8\%) 변형이 발생하였으며, $180-420$ $\mathrm{kPa}$ 압력 범위에서는 압축변형율이 $5.8 \%$ 이하이면서 그림 3(b)와 같이 접합이 이루어졌다. 그림 5는 그림 3(b)와 (c)에 $\mathrm{A}$ 와 $\mathrm{B}$ 로 표시된 영역을 확대한 사진이다. 압축변형률이 $5.8 \%$ 인 폼은 변형된 모습을 구별하기가 힘들고, cell 형상을 그대로 유지하고 있지만, 압축변형률이 $40.8 \%$ 인 폼은 cell 형 상이 변형되었고, 폼의 strut가 파단되거나, 입계균열이 발생 하였다. 접합압력이 $100 \mathrm{kPa}$ 이하로 너무 낮으면 접합이 되 지 않고, $500 \mathrm{kPa}$ 이상으로 너무 높아도 strut에서 균열과 파 단이 발생하여 폼 형상이 압축 방향으로 변형이 되기 때문에,
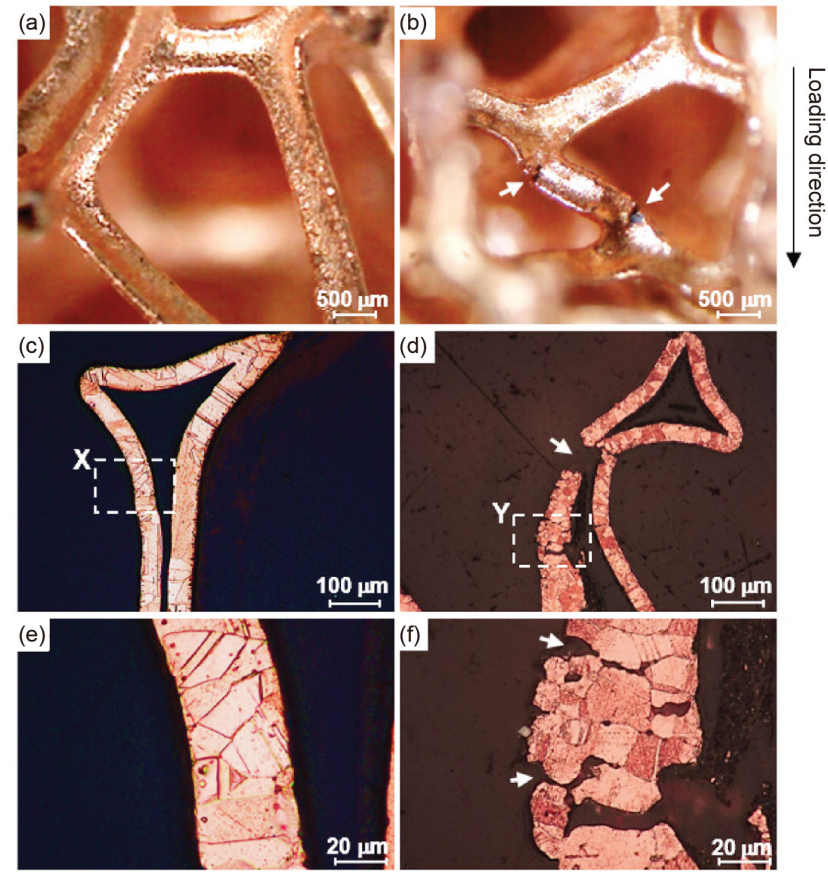

Fig. 5. Close-up image and macrostructure denoted as $A(a, c)$ and $\mathrm{B}(\mathrm{b}, \mathrm{d})$ in Fig. 4, respectively. (e), (f) microstructures at region denoted as $\mathrm{X}$ and $\mathrm{Y}$ in (c) and (d), respectively [bonding conditions: $800{ }^{\circ} \mathrm{C}, 60 \mathrm{~min}$, and (a,c,e) 420 and (b,d,f) $500 \mathrm{kPa}$.

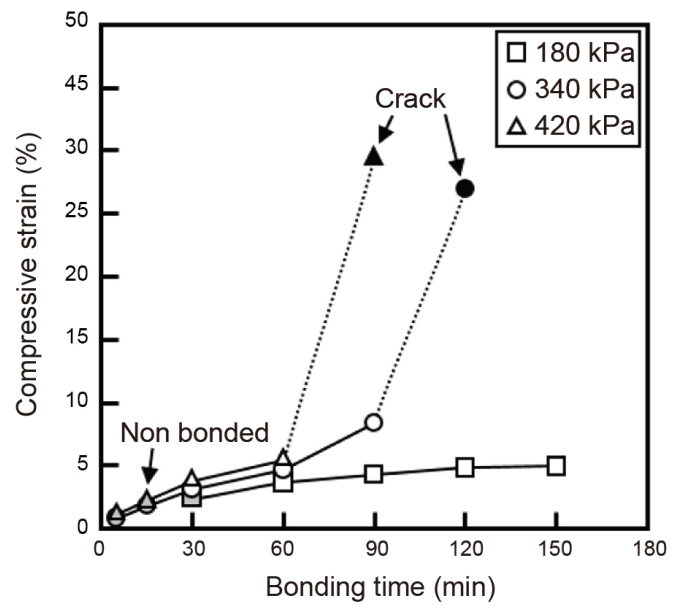

Fig. 6. Compressive strain of $\mathrm{Cu}$ foam with bonding pressure and time at $800{ }^{\circ} \mathrm{C}$.

적정 접합압력은 $180-420 \mathrm{kPa}$ 범위인 것으로 생각되었다. 상 기의 결과를 근거로, 접합이 가능하고 변형이 적은 접합압력 세 조건 $(180,340,420 \mathrm{kPa})$ 을 선정한 후, 유지시간에 따른 접 합 유무와 압축변형율을 검토하여 그림 6에 나타내었다. 이 결과로부터, $340 \mathrm{kPa}$ 과 $420 \mathrm{kPa}$ 에서 30 분 이상, $180 \mathrm{kPa}$ 에서 는 60 분 이상 유지하여야만 접합이 이루어지는 것을 알 수 있 

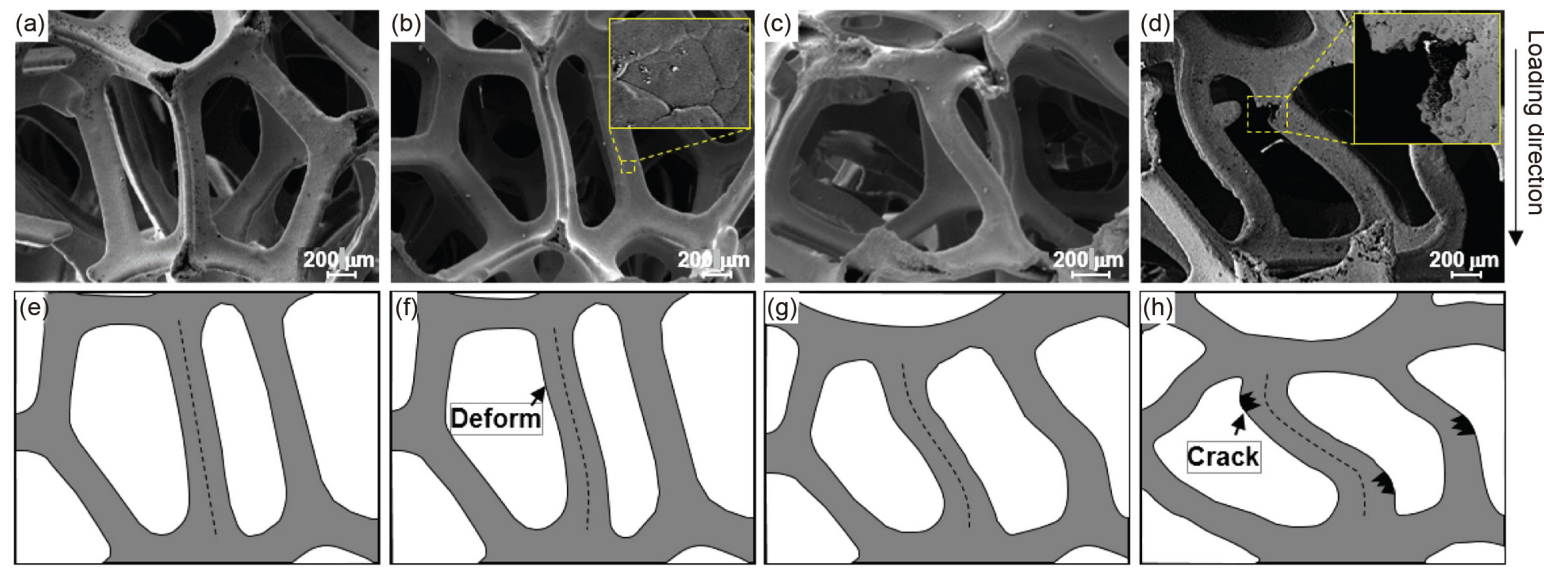

Fig. 7. (a d) SEM micrograph of $\mathrm{Cu}$ foam and $(\mathrm{e} \sim \mathrm{h})$ schematic illustration of deformation procedure with compressive strain (a,e) $0 \%$, (b,f) $5 \%,(\mathrm{c}, \mathrm{g}) 8 \%$, and (d,h) $28 \%$. diffusion bonded at $800{ }^{\circ} \mathrm{C}, 340 \mathrm{kPa}$, and (b) $60 \mathrm{~min}$, (c) $90 \mathrm{~min}$, and (d) $120 \mathrm{~min}$.

다. 또한 strut에서 균열이 발생하는 접합압력과 유지시간의 상관관계는 접합압력이 높을수록 단시간 쪽에서 발생하였 다. 즉 $420 \mathrm{kPa}$ 에서는 90 분, $340 \mathrm{kPa}$ 에서는 120 분에서 발생 하지만, $180 \mathrm{kPa}$ 에서는 150 분 유지하여도 발생하지 않았다.

접합과정에서 폼의 변형과정을 검토하기 위하여, $340 \mathrm{kPa}$ 의 접합압력에서 유지시간(압축변형율)에 따른 폼 내부의 strut 형상 변화를 관찰하였다. 그림 7(a)는 접합을 실시하지 않은 폼의 형상이고, (b)-(d)는 각각 $60,90,120$ 분 동안 유지 하여 접합한 폼 내부의 strut 형상을 나타낸 SEM 이미지이며, (e)-(h)는 SEM 이미지를 근거로 나타낸 모식도이다. 유지시 간이 증가함에 따라, 60 분에서는 압축응력 방향과 평행한 strut가 미소하게 변형되었고, 90 분에서는 $\mathrm{S}$ 자형으로 좌굴 (buckling)되었으며, 120 분에서는 변형이 가장 많이 발생한 nose에서 균열이 발생하였다. (d)와 (h)에서 알 수 있는 바와 같이 균열은 인장응력이 가장 많이 부가되는 곳에서 발생하 였다. Anthony Burteau [21]는 $900{ }^{\circ} \mathrm{C}$ 의 온도에서 $0.12 \mathrm{MPa}$ 의 압축하중을 받는 니켈폼 내 셀의 변형과정을 $3 \mathrm{D}-$ 유한요 소해석 기법으로 해석한 결과, node 영역은 거의 변형되지 않 지만 대부분의 변형은 압축하중과 거의 같은 방향으로 배열 된 strut에서 국부적으로 발생하며, strut의 양 끝단에 서로 반 대방향으로 형성되는 국부변형으로부터 전단변형에 의해 strut가 S자 형태로 변형된다고 보고하였다. 이때, 전단에 의 해 형성되는 변형은 크립-벤딩(creep-bending)이며 [22,23], 유지시간이 길어질수록 $\mathrm{S}$ 자 node에서 크립-벤딩에 의한 변 형이 증가하는 것으로 보고되고 있다 [24]. 본 실험에서도 접 합압력에 의한 node 영역의 변형은 거의 없지만, 전단변형에 의해 strut가 $\mathrm{S}$ 자 형태로 변형되고, 유지시간이 길어질수록 $\mathrm{S}$
자 node 근방에서 크립-벤딩에 의해 국부적으로 변형이 증가 하기 때문에 이곳에서 균열이 발생하는 것으로 생각된다.

한편 가는 와이어(wire)를 고온으로 장시간 가열하는 경 우, 표면과 접하는 결정입계는 길이 방향으로 성장하기가 어 렵기 때문에 두께 방향으로 주로 성장하여 그림 5 (f)와 같이 두께 방향으로 관통하는 형상으로 성장한다. 또한 고온에 노 출된 금속의 표면에서는 그림 7 (b)에서 구리폼의 표면을 확 대한 사진과 같이 표면과 접하는 결정입계가 확산과 증발에 의해 V형으로 파이는 서멀그루빙(thermal grooving)이 일어 난다. 이러한 현상 때문에 $\mathrm{S}$ 자 형으로 변형된 strut의 node는 노치(notch)로 작용하고, 크립-벤딩에 의해 입계에 따라 균열 이 발생하는 것으로 생각된다.

\section{2 접합부 인장하중에 미치는 접합조건의 영향}

접합이 가능하고 셀에 균열이 발생하지 않은 조건만을 선 정하여, 접합압력과 유지시간에 따른 접합부의 인장하중 변 화를 검토하여 그 결과를 그림 8에 나타내었다. 각 접합압력 에서 유지시간에 따른 인장하중 변화의 특징은 접합시간이 일정 시간 이상 유지되면 인장하중이 급격히 증가한 후, 서서 히 증가하는 것이다. 또한 각각 접합압력에서 최고 인장하중 의 값은 거의 비슷한 값을 나타낸다. 또한 인장하중 값은 접합 조건과 관계없이 91.0-107.0 N 범위의 낮은 그룹(L)과 130.7$146.8 \mathrm{~N}$ 범위의 높은 그룹(H), 2그룹으로 나누어지는 것이 특 징이다. 인장 시험 후 파단된 시험편의 거시파면을 분석한 후 그 결과를 그림 9에 나타내었다. 그림 9(a)는 판재 측 파면이 고, (b)는 폼 측 파면의 SEM 이미지를 나타낸 것이다. 그림 9(a)로부터 판재 측 파면에서는 삼각형의 점(S 영역) 또는 삼 


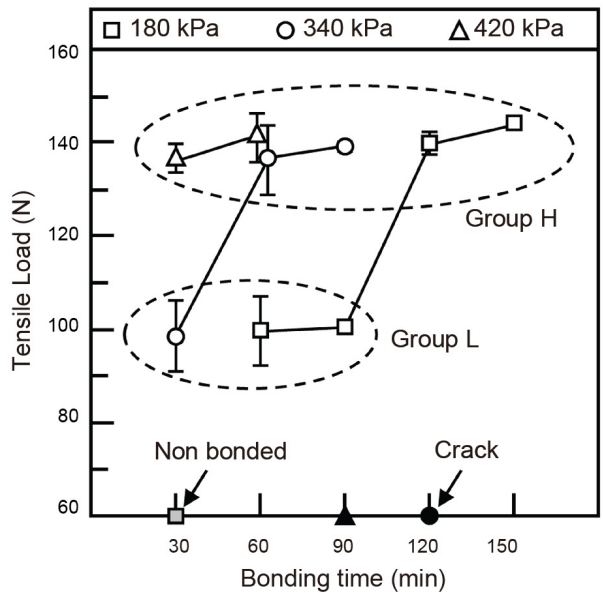

Fig. 8. Tensile load of diffusion bonded $\mathrm{Cu}$ foam $/ \mathrm{Cu}$ plate joint with bonding pressure and time at $800{ }^{\circ} \mathrm{C}$.

각형이 선으로 이어져 있는 리본 형상(N 영역)이 불규칙하게 분포되어 있는 것을 알 수 있다. 또한 판재 측(a)에서 보이는 삼각형과 리본 형상을 폼 측(b)과 비교한 결과, 삼각형 $(\mathrm{S}$ 영 역)은 strut의 파면인 것을 알 수 있고, 리본 형상 (N 영역)은 strut가 모이는 node와 일치하는 것을 알 수 있다. 금속폼을 이 루는 셀은 규칙적인 구조를 갖는데 반해 strut 혹은 node의 파 면 형상이 모두 제각각으로 불규칙하게 나타나는 이유는 셀 의 절단 위치가 다르기 때문이다. 그림 9(c)는 폼을 구성하고 있는 셀 형상의 모식도를 나타낸 것이다. 이것으로부터 셀 형 상은 5 각 12 면체의 규칙성을 가지지만 각 셀의 축이 어긋나 있는 형상을 가지기 때문에 접합을 위한 절단 시 피접합면의 형상이 각기 다르게 나타난다. 그림 9(d)는 절단면이 strut를 가로지를 경우이며, 이 경우 피접합면이 그림 9(a)의 S 영역과 같이 삼각형 형상으로 나타나는 것이다. 그림 $9(\mathrm{e})$ 는 절단면 이 node를 가로지르는 경우이며, 이 경우 피접합면이 그림 9(a)의 N 영역과 같이 리본 형상으로 나타난다.
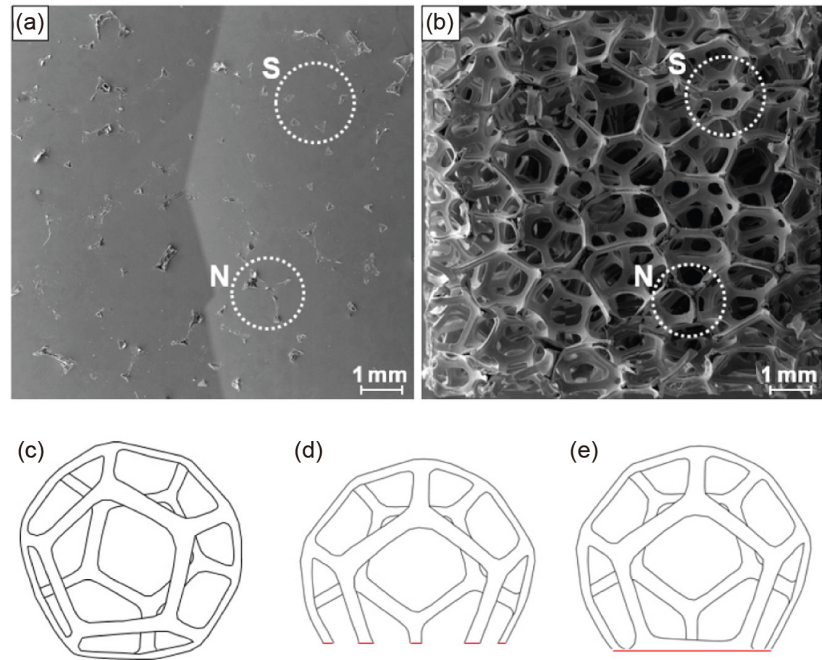

Fig. 9. Macro-fractography of (a) plate and (b) foam. Schematic diagram of (c) pentagonal dodecahedron and cell structure grinded until (d) strut and (e) node.

접합부의 인장하중 변화는 파단 형상과 밀접한 관계가 있 기 때문에, 접합조건에 따라 접합부의 인장하중이 두 그룹으 로 나누어지는 이유를 알기 위하여 각 그룹의 대표적인 파면 형상을 관찰하고 비교하였다. 그림 10 은 L그룹의 대표적인 파면으로 $180 \mathrm{kPa}$ 에서 60 분 유지한 인장시편 $(92.4 \mathrm{~N})$ 의 판재 측 파면을 SEM으로 관찰한 결과이고, (a)는 판재 측의 거시 파면을 나타낸 것이다. (b)는 node 접합부의 파면(A)을 확대 한 것으로, 접합부의 모서리 $\left(\mathrm{A}_{1}\right)$ 는 융기된 형상인 반면 중심 부 $\left(\mathrm{A}_{2}\right)$ 는 판재와 거의 동일한 높이를 갖는다. 각 영역을 확대 하여 관찰해 보면, $\mathrm{A}_{1}$ 영역을 확대한 (c)와 같이 모서리는 얕 은 딤플(dimple) 파면과 파면 높이가 높은 영역이 혼재된 것 을 알 수 있다. 파면의 높이가 높은 영역은 최종파단부가 선 상으로 될 때까지 소성변형한 후에 파단 된 폼측 모재파단 (foam fracture, F.F) 영역이며, 폼의 제작과정(open cell 구조 의 폴리머 표면에 전기 도금 방식으로 금속층을 성장시킨 후,
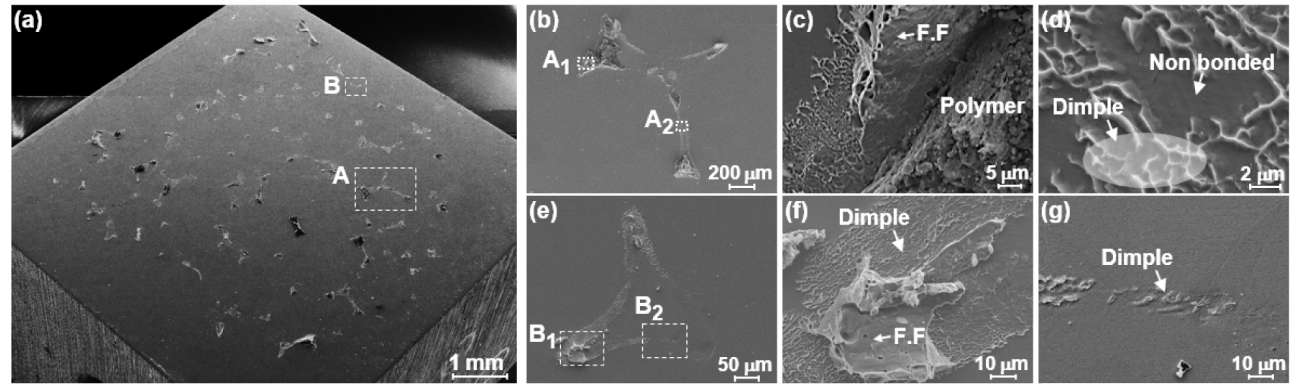

Fig. 10. Fractured surface of group L: (a) macro SEM image of plate side, (b) A region in (a), (c) $A_{1}$ region in (b), (d) $A_{2}$ region in (b); (e) $\mathrm{B}$ region in (a), (f) $\mathrm{B}_{1}$ region in (e) and, $(\mathrm{g}) \mathrm{B}_{2}$ region in (e) [bonding conditions : $800{ }^{\circ} \mathrm{C}, 60 \mathrm{~min}$, and $180 \mathrm{kPa}$ ]. 

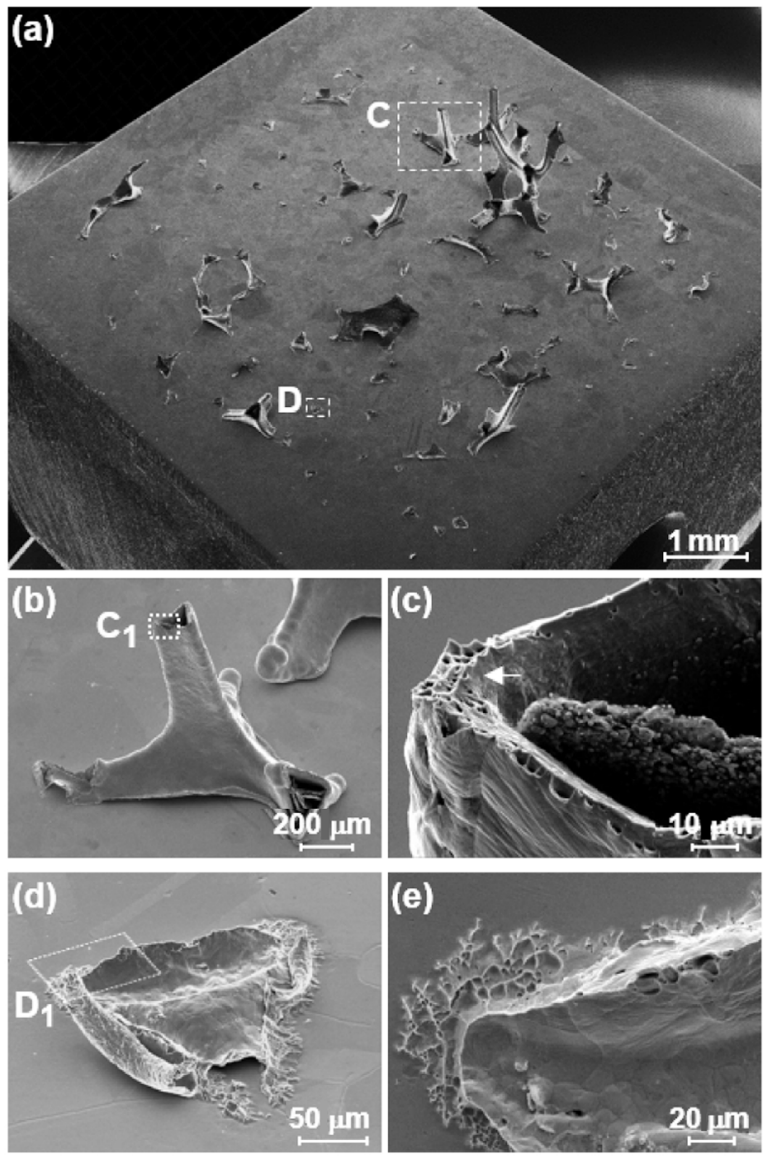

Fig. 11. Fractured surface of group H: (a) macro SEM image of plate side, (b) $\mathrm{C}$ region in (a), (c) $\mathrm{C}_{1}$ region in (b), (d) D region in (a), and (e) $\mathrm{D}_{1}$ region in (f) [bonding conditions: $800{ }^{\circ} \mathrm{C}, 60 \mathrm{~min}$, and $420 \mathrm{kPa}$ ].

열처리를 통해 폴리머를 제거하여 제작 됨)에서 잔류한 폴리 머가 일부 혼재함을 알 수 있다. 중심부는 $\mathrm{A}_{2}$ 영역을 확대한 (d)와 같이 소성변형한 흔적인 딤플과 변형 없이 평탄한 면이 혼재되어 있는 것으로부터 계면파단 되었음을 알 수 있다. 한 편 (e)는 strut 접합부의 파면(B)을 확대한 것으로, node의 경 우와 유사하게 모서리 $\left(\mathrm{B}_{1}\right)$ 에서 일부 폼측 모재파단이 발생하 고, 대부분 딤플 파면과 미접합부 $\left(\mathrm{B}_{2}\right)$ 로 이루어져 계면파단 되었음을 알 수 있다. 즉, 인장하중이 낮은 $\mathrm{L}$ 그룹은 접합부 모서리에 존재하는 일부 모재파면과 대부분의 계면파면으로 이루어져 있었다. 그림 11은 $\mathrm{H}$ 그룹의 대표적인 파면으로, $420 \mathrm{kPa}$ 에서 60 분 유지한 인장시편 $(147.8 \mathrm{~N})$ 의 판재 측 파면 과 이에 대응하는 폼측의 파면을 $\mathrm{SEM}$ 으로 관찰한 결과이고, (a)는 판재 측의 파면을 나타낸 것이다. (b)는 node 접합부의 파면(C)을 확대한 것으로, strut 길이의 약 $1 / 4$ 지점에서 파단 되었으며, (b)의 파단부 $\left(\mathrm{C}_{1}\right)$ 를 확대한 (c)의 파면으로부터 최 종파단부가 선상으로 될 때까지 소성변형한 후에 파단된 것

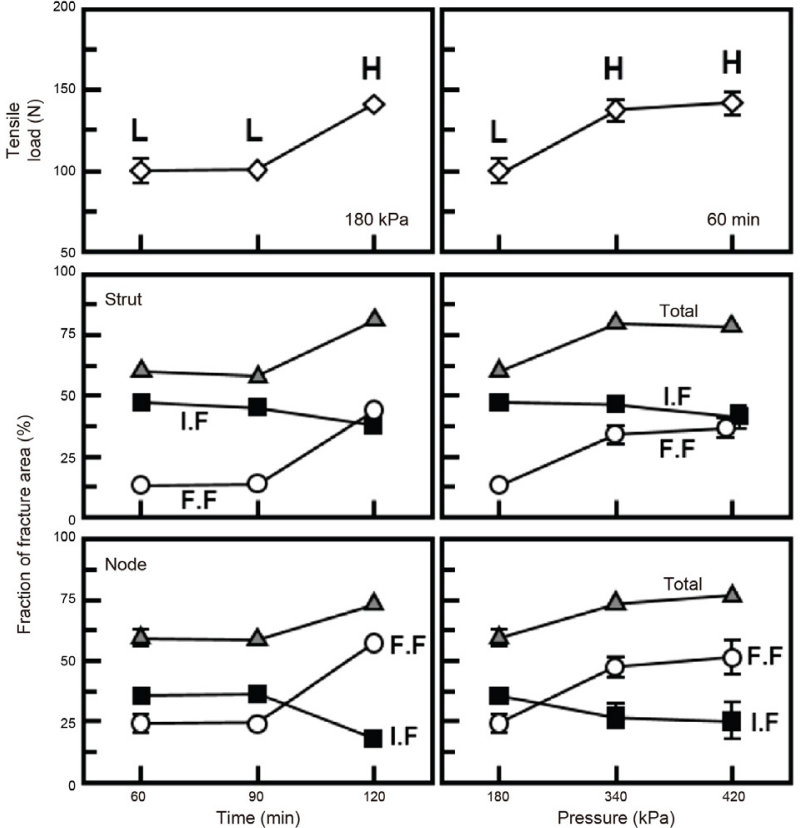

Fig. 12. Typical fracture area and tensile load with bonding time and bonding pressure at $800{ }^{\circ} \mathrm{C}$.

을 알 수 있다. 이 결과로부터, node와 판재의 접합이 잘 이루 어져 접합부 면적이 윗부분인 strut 면적보다 충분히 클 때, strut에서 파단이 일어난다는 것을 유추할 수 있다. 한편 (d) 는 strut의 파단부인 (a)의 $\mathrm{D}$ 를 확대한 것이고, (e)는 (d)의 $\mathrm{D}_{1}$ 영역을 확대한 SEM 이미지이다. 판재의 파면 높이가 높은 것으로부터 대부분 폼재에서 파단 되었지만, (e)에서 얕은 딤 플이 관찰되므로 일부는 계면에서 파단되었음을 알 수 있다. 이 파면에서 미접합부는 발견되지 않았다.

파면분석 결과로부터, 파단 형상은 strut 자체에서 파단되 거나 폼측 일부가 소성변형한 후 파단되는 모재파단과 strut 혹은 node와 판재 사이의 계면에서 딤플 파면으로 나타나는 계면파단 그리고 평탄한 면으로 나타나는 미접합부로 분류 할 수 있다. 또한 인장하중이 낮은 L그룹은 계면파면이 많은 파단형상이었고, 인장하중이 높은 $\mathrm{H}$ 그룹은 모재파면이 많은 파단형상이었다. 두 그룹에서 파단 형상의 차이가 발생하는 이유는 접합압력, 유지시간이 증가함에 따라 접합부 면적이 달라지기 때문인 것으로 예상된다. 일반적인 벌크(bulk) 소재 간 접합부는 단면을 통해 접합면적 등을 평가할 수 있으나, 금속폼의 접합부는 수십 개의 strut와 node의 접합부로 이루 어져 있기 때문에 단면으로는 대략 3 5개의 접합부만을 확인 할 수 있고, 이는 전체 접합부를 대변할 수 없다. 따라서 본 연 구에서는 모재파단과 계면파단이 발생한 영역을 접합된 영 

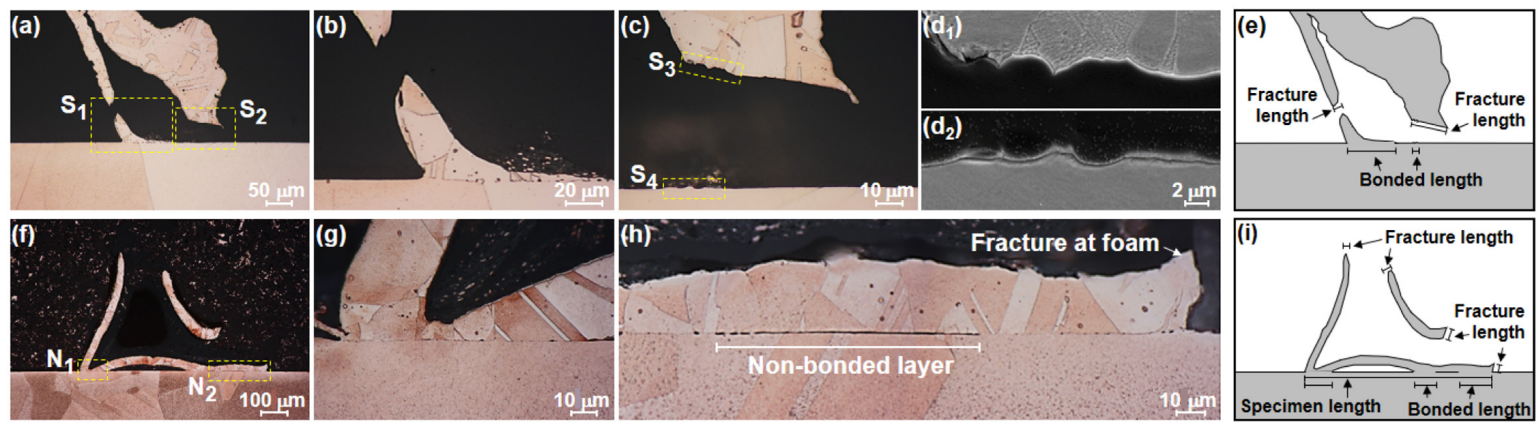

Fig. 13. Cross-section images of $(a \sim d)$ strut and $(f \sim h)$ node fractured at foam: $(b, c) S_{1}$ and $S_{2}$ region in $(a),\left(d_{1-2}\right) S_{3}$ and $S_{4}$ region in (c), and $(g, h) N_{1}$ and $N_{2}$ region in (f). (e, i) Schematic illustration of bonded length and fracture length at strut and node, respectively.

역으로 가정하고, 접합조건에 따른 파면 면적 변화를 조사하 여 인장하중과의 관계를 고찰하였다.

그림 12 는 strut와 node 각각의 형상에 대하여, 전체 피접 합 면적에서 계면파면과 모재파면이 차지하는 면적 분율을 접합부 인장하중과 접합압력, 유지시간의 변화에 따라 비교 한 결과이다. 계면파면은 딤플 파면의 면적을 측정하였으며, 모재파면은 최종파단부가 소성변형 후에 축소된 면적으로 나타나기 때문에, 모재파단부의 파단 길이와 폼재의 평균 두 께의 곱으로써 파단 전의 면적을 유추하여 사용하였다. 이 결 과로부터, 접합압력과 유지시간이 증가함에 따라 모재파면 과 계면파면(interfacial fracture, I.F)의 면적 합(total)이 증가 하고, 이에 따라 접합부의 인장하중도 동일한 경향으로 증가 함을 알 수 있다. 또한 인장하중이 높은 H그룹은 L그룹에 비 해 모재파면의 분율이 크고 계면파면의 분율이 적은 것으로 부터, 모재파면의 분율이 접합부의 인장하중에 큰 영향을 미 치는 것을 알 수 있다. 미접합부를 제외한 파단 면적의 합이 계면에서 접합된 면적과 비례한다고 가정했을 때, 전체 파단 면적의 합이 클수록 모재파면의 분율은 높은 반면 계면파면 의 분율이 낮은 것으로부터, 접합된 면적이 클수록 모재파단 이 많아지는 것으로 생각된다. 한편, strut와 node 각각의 형 상에 대한 면적 분율의 차이를 관찰해보면, 접합조건에 따른 모재파면의 면적 분율 변화는 strut와 node에서 동일한 경향 으로 나타나지만, 분율 값은 동일한 접합조건에서 node가 strut에 비해 높다. 즉, 접합부 인장하중은 파단 된 면적(접합 된 면적)에 따라 증가하며, 모재파단은 strut에 비해 node에서 더 많이 발생한다.

strut와 node 즉, 피접합면의 형상에 따라 계면파단과 모재 파단의 분율 차이가 발생하는 원인은 strut와 node에서 파단 된 시편의 단면 미세조직을 비교하면 알 수 있을 것으로 예상 되어, 피접합면의 형상과 파단부의 단면 미세조직 사이의 상
관관계를 검토하였고, 그 결과를 그림 13 에 나타내었다. 그림 13은 strut(a e)와 node(f i)에서 파단된 시편의 대표적인 단 면 미세조직을 나타낸 것이다. (a)는 하나의 strut가 판재와 접 합된 후 파단 된 영역의 단면 이미지로, 좌측은 모재파단이 발생했으나, 우측은 계면 근처에서 파단되었다. 파단된 시편 의 단면에서 하나의 strut가 두 개로 분리되어 보이는 이유는 폼재의 내부가 비어있는 가지 형상을 가지기 때문이다. (b)는 (a)의 $\mathrm{S}_{1}$ 을 확대한 것으로 strut에서 모재 파단이 발생한 영역 은 폼과 판재의 계면이 완전하게 접합되었고, 접합계면의 좌 측 끝단에서 일부 양 모재의 결정립이 서로 합체된 것을 볼 수 있다. (c)는 (a)의 $\mathrm{S}_{2}$ 를 확대한 것이고, $\left(\mathrm{d}_{1-2}\right)$ 는 (c)의 $\mathrm{S}_{3}, \mathrm{~S}_{4}$ 를 확대한 SEM 이미지로, 양측 모재가 연신된 형상이므로 계면파단 영역이다. 이것으로부터 (c)와 같이 평탄한 미접합 부가 존재하는 영역에서는 일부 접합된 영역에서 (d)와 같은 계면파단이 발생함을 알 수 있다. (f)는 node가 접합된 후 파 단 된 영역의 단면 이미지로, strut와의 이음부인 상부와 우측 에서 완전하게 모재파단 되었다. (g)와 (h)는 (f)의 $\mathrm{N}_{1}, \mathrm{~N}_{2}$ 를 각각 확대한 것으로, node의 접합부는 strut의 접합계면에 비 해 긴 접합계면을 가지며, 전체 접합계면이 완전하게 접합된 영역과 미접합부가 혼재되어 있음에도 불구하고, 폼측 모재 에서 파단되었다.

단면분석 결과로부터, 파단 길이와 접합부 길이를 나타낸 (e), (i)의 모식도와 같이 접합부 길이가 파단 길이보다 충분 히 클 때 모재파단이 발생하고, 접합부의 길이는 strut에 비해 node에서 더 길기 때문에 모재파단은 strut에 비해 node에서 더 많이 발생하는 것으로 예상되었다. 모재 파단과 계면파단 이 발생하는 영역의 접합부 미세조직을 자세하게 살펴보기 위하여 각각 모재 파단과 계면파단이 발생할 것으로 예상되 는 접합부 단면에서 추방산란전지-회절(electron back scattered diffraction, EBSD) 분석을 실시하였고, 그 결과를 


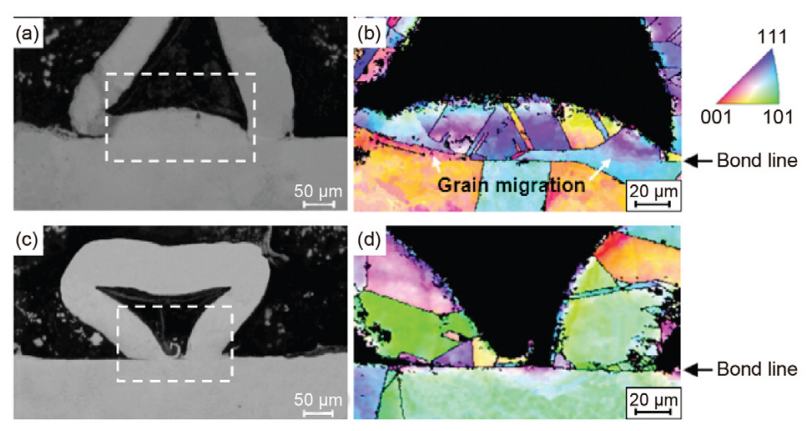

Fig. 14. (a,c) Optical micrograph and (b,d) IPF image of diffusion bonded joint at $(a, b)$ foam fracture and $(c, d)$ interface fracture region. (black line: boundary having more than 15 degree misorientations) [bonding conditions: $(\mathrm{a}, \mathrm{b}) 800{ }^{\circ} \mathrm{C}, 120 \mathrm{~min}$, and $180 \mathrm{kPa}$ and $(\mathrm{c}, \mathrm{d}) 800{ }^{\circ} \mathrm{C}, 60 \mathrm{~min}$, and $\left.180 \mathrm{kPa}\right]$

그림 14에 나타내었다. EBSD 분석 결과는 결정방위에 따라 색상을 다르게 나타내는 역극점도(inverse pole figure, IPF) 로 나타내었으며, 접합계면에서의 결정립 합체 유무를 관찰 하기 위해 결정방위차가 $15^{\circ}$ 이상인 고경각립계를 검은선으 로 표시하였다. $180 \mathrm{kPa}$ 의 압력조건에서 120 분 간 유지된 접 합 계면의 미세조직은 그림 14(b)의 IPF 이미지와 같이 접합 된 계면에서 양 모재의 결정립이 서로 합체되고, 입계이동이 진행이 된 것을 알 수 있다. 반면, 같은 압력조건에서 60 분 간 유지된 접합계면의 미세조직은 광학현미경 상에서 접합이 된 것처럼 보이나, 그림 14(d)의 IPF 이미지와 같이 접합된 계 면에서 검은 선이 관찰되므로, 결정립의 이동 및 합체는 전혀 일어나지 않았다. 결정립의 이동 및 합체 현상은 유지시간이 길수록 증가하고, 접합된 계면의 길이 또한 증가한다. 따라서 인장하중이 낮은 $\mathrm{L}$ 그룹은 접합계면에서 결정립의 이동 및 합체가 발생할 만큼의 유지시간이 충분하지 않기 때문에 계 면에서 파단되고, 인장하중이 높은 $\mathrm{H}$ 그룹은 접합계면에서 결정립의 이동 및 합체가 발생할 만큼의 유지시간이 충분하 기 때문에 계면에서 접합이 완전히 이루어져 모재에서 파단 되는 것으로 생각된다.

그림 15 는 계면파단 영역과 모재파단 영역의 strut와 node 각각에 대하여, 파단 길이 대비 접합부 길이 $\left(L_{\mathrm{bonded}} / L_{\mathrm{fracture}}\right)$ 와 접합률을 나타낸 것이다. 계면파단 영역의 접합률은 그림 13(d)와 같이 파면으로부터 측정된 피접합면적 대비 접합된 면적으로 정의하였다. 모재파단 영역은 파면에서 접합계면 을 관찰 할 수 없으므로, 그림 15(i)와 같이 단면으로부터 측 정된 전체 접합계면 길이 대비 접합된 길이를 접합률로 정의 하였다. 계면파단이 발생한 영역은 파단 길이 대비 접합부 길 이가 1 보다 낮은 값을 가지는 반면, 모재파단이 발생한 영역

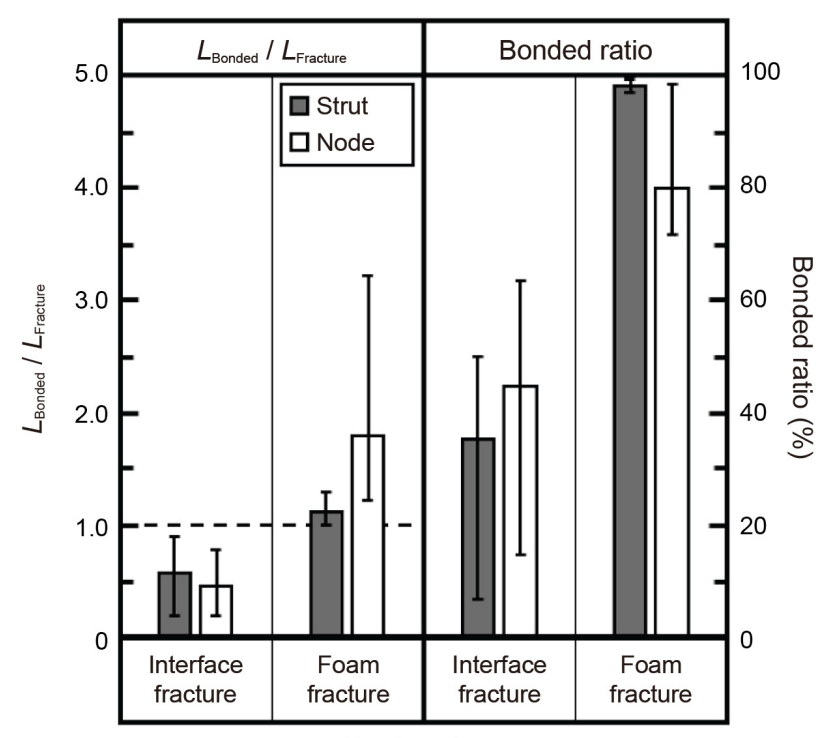

Fracture type

Fig. 15. $\left(L_{\text {bonded }} / L_{\text {fracture }}\right)$ and bonded ratio of strut and node with fracture group

은 모두 1 보다 높은 값을 가진다. 이는 파단 면적에 비해 접합 면적이 좁은 경우 계면파단이 발생하고, 반대로 접합 면적이 넓은 경우엔 비교적 면적이 좁은 폼측에서 파단이 발생함을 의미한다. 한편, 모재파단이 발생한 영역은 strut에서 약 $98.1 \%$, node에서 약 $79.8 \%$ 의 접합률을 갖는다. 즉, strut는 거 의 모든 피접합면이 접합되어야만 모재파단이 발생하는 반 면, node는 약 $80 \%$ 의 접합률만 만족하더라도 모재파단이 가 능하다. 따라서 strut에 비해 node에서 모재파단의 분율이 큰 이유는 strut에 비해 넓은 피접합 면적을 갖는 형상이기 때문 에, 모든 계면이 접합되지 않더라도 node와 연결된 strut의 단 면적보다 접합부의 면적이 넓으면 strut에서 모재파단이 발생 하는 반면, strut는 피접합면의 면적과 strut의 단면적이 거의 동일하여 모재에서 파단되기 어렵기 때문이다.

\section{4. 결 론}

구리판과 구리폼에 대하여 고상확산접합을 실시한 후, 접 합압력과 유지시간에 따른 폼의 변형과 접합부 인장성질 변 화를 검토한 결과, 다음과 같은 결론을 얻었다.

1) 접합압력과 유지시간이 증가할수록 접합된 폼의 압축 변형률이 증가하였다. 또한 $340 \mathrm{kPa}$ 이상의 압력조건에서 90 분을 초과하여 유지한 경우, 폼의 압축변형률이 $25 \%$ 이상으 로 급격하게 증가하였고, 균열이 발생하였다. 균열은 압축하 중에 의해 $\mathrm{S}$ 자로 변형된 strut의 양 끝단에서 결정립계를 따 
라 형성되었다.

2) 접합부의 인장하중은 $30 \mathrm{~min}-420 \mathrm{kPa}, 60 \mathrm{~min}-340 \mathrm{kPa}$, $120 \mathrm{~min}-180 \mathrm{kPa}$ 조건을 기준으로, 인장하중이 낮은 그룹(L) 과 높은 그룹(H)으로 나누어진다. L그룹은 주로 계면에서 파 단이 발생하는 반면 $\mathrm{H}$ 그룹은 주로 폼측 모재에서 파단이 발 생하였다. 접합부의 인장하중은 파단된 면적(접합된 면적)과 비례하여 증가했으며, 파단된 면적 중에서는 모재파면의 분 율이 접합부의 인장하중에 큰 영향을 미치는 것으로 생각된 다. 한편, 모재파단은 접합된 면적이 폼측에서 파단 된 영역 의 단면적보다 넓은 경우에만 발생하였다. 따라서 상기 접합 조건을 기준으로, $\mathrm{H}$ 그룹은 접합된 면적이 폼측의 단면적을 초과하여 모재파단이 발생하고, 접합부 인장하중이 높은 것 으로 생각된다.

3) 모재파단은 strut에 비해 node의 접합부에서 더 많이 발 생하였다. 모재파단이 발생하기 위한 임계 접합률은 strut에 서 $98.1 \%$, node에서 $79.8 \%$ 로, strut는 거의 모든 피접합면이 접합되어야만 모재파단이 발생하는 반면, node는 약 $80 \%$ 의 접합률만 만족하더라도 모재파단이 가능한 것으로 판단된 다. 이는 node의 피접합 면적이 strut에 비해 넓어, 비교적 낮 은 접합률을 갖더라도 폼측의 단면적보다 접합부의 면적이 넓을 확률이 높기 때문인 것으로 생각된다.

\section{감사의 글}

본 연구는 2015년도 산업통상부의 재원으로 한국에너지 기술평가원(KETEP)의 지원을 받아 수행한 연구 과제입니다 (No. 20132020000390).

\section{REFERENCES}

1. J. Banhart, Prog. Mater. Sci. 46, 559 (2001).

2. J. M. Jang, W. S. Lee and S. H. Ko, J. Kor. Inst. Met. \& Mater. 43, 292 (2005).

3. X. Han, IRACC, p.16, Purdue e-Pubs, West Lafayette,
USA (2012).

4. S. H. Chung and Y. J. Oh, J. Kor. Inst. Met. \& Mater. 40, 507 (2002).

5. S. H. Chung and Y. J. Oh, J. Kor. Inst. Met. \& Mater. 40, 512 (2002).

6. A. Bhattacharya, V. V. Calmidi and R. L. Mahajan, Int. J. Heat Mass Transf. 45, 1017 (2002).

7. W. Lu, C. Y. Zhao and S. A. Tassou, Int. J. Heat Mass Transf. 49, 2751 (2006).

8. N. Tsolas, Ph. D. Thesis, pp.2-4, University of Toronto, Toronto (2010).

9. C. Y. Zhao, Int. J. Heat Mass Transf. 55, 3618 (2012).

10. Z. Liu, Y. Yao and H. Wu, Appl. Energy. 112, 1222 (2013).

11. N. Movahedi, S. M. H. Mirbagheri and S. R. Hoseini, Met. Mater. Int. 20, 757 (2014)

12. S. Kang, J. W. Lee, S. K. Hyun, B. P. Lee, M. G. Kim and Y. J. Kim, Korean J. Met. Mater. 52, 203 (2014).

13. P. De Jaeger, C. T'Joen, H. Huisseune, B. Ameel, S. De Schampheleire and M. De Paepe, Int. J. Heat Mass Transf. 55, 6200 (2012).

14. T. Jarvis, W. Voice and R. Goodall, Mater. Sci. Eng. A-Struct. Mater. Prop. Microstruct. process. 528, 2592 (2011).

15. Y. Huang, J. Gong, S. Lv, J. Leng and Y. Li, Mater. Sci. Eng. A-Struct. Mater. Prop. Microstruct. process. 552, 283 (2012).

16. M. Singh, R. Asthana, A. L. Gyekenyesi and C. E. Smith, Int. J. Appl. Ceram. Technol. 9, 657 (2012).

17. U. Reisgen, J. Eng. Gas. Turbines Power-Trans. ASME 132, 054502-1 (2010).

18. A. A. Shirzadi, M. Kocak and E.R. Wallach, Sci. Technol. Weld. Join. 9, 277 (2004).

19. B. Hamilton, S. Oppenheimer, D. C. Dun and D. Lewis, Metall. Mater. Trans. B-Proc. Metall. Mater. Proc. Sci. 44, 1554 (2013).

20. J. W. Elmer, J. Klingmann, and K. Van Bibber, Phys. Rev. Spec. Top Accel. Beam. 4, 053502 (2001).

21. A. Burteau, J. D. Bartout, Y. Bienvenu and S. Forest, $C$. R. Phys. 15, 705 (2014).

22. E. W. Andrews, L. J. Gibson and M. F. Ashby, Acta Mater. 47, 2853 (1999).

23. A. C. F. Cocks and M. F. Ashby, Acta Mater. 48, 3395 (2000).

24. T. J. Chen and J. S. Huang, Acta Mater. 57, 1497 (2009). 